\title{
Psicooncología
}

ISSN: 1696-7240

\section{Early detection of breast cancer: the role of risk perception and family history}

\author{
Carolina Ribeiro Seabra ${ }^{1}$; Ana Carolina Peuker²; Maria Júlia Armiliato ${ }^{3}$; Miguel Luis Alves \\ de Souza ${ }^{4}$; Elisa Kern de Castro ${ }^{5 *}$
}

Recibido: 12 de diciembre de 2016 / Aceptado: 1 de abril de 2017

\begin{abstract}
Background: Breast cancer is the neoplasm with the highest mortality rates among Brazilian women. Family history plays an important role in tracking the illness because its analysis reveals possible genetic risks. Objective: The aim of this study is to compare the risk perception and self-care for breast cancer among healthy women with and without family history. Method: The study included 211 women $($ mean age $=59.11$ years, $\mathrm{SD}=8.54)$ of which $55(26.4 \%)$ had a family history of the illness . The instruments used were a sociodemographic and health behavior questionnaire and a risk perception questionnaire. Results and Conclusions: The results showed no significant differences in risk perception and self-care behavior among women with and without breast cancer history, signaling the need of guidelines for psychologists to act in breast cancer prevention among women with a family history, encompassing understanding of the risk factors and causes of the illness as well as women's responsibility in tracking.
\end{abstract}

Keywords: Cancer; breast cancer; self-regulation; self-care; illness prevention.

\section{[en] Detección precoz del cáncer de mama: el papel de la percepción de riesgo y la historia familiar}

Resumen. Introducción: el cáncer de mama es el segundo tipo de neoplasia con más mortalidad entre las mujeres brasileñas. La historia familiar tiene un papel importante, pues su análisis permite identificar posibles riesgos genéticos. Objectivo: comparar la percepción de riesgo y el autocuidado del cáncer de mama en mujeres sanas con y sin historia familiar de la enfermedad. Método: Participaron 211 mujeres (edad media $=59,11$ años, DT= 8,54$)$, de las cuales $55(26,4 \%)$ tenían historia familiar de la enfermedad. Los instrumentos utilizados fueron un cuestionario sociodemográfico y de conductas de salud y un cuestionario de percepción de riesgo.

1 Programa de Pós-Graduação em Psicologia, Centro de Ciências da Saúde

E-mail: carolrseabra@gmail.com

2 Programa de Pós-Graduação em Psicologia, Centro de Ciências da Saúde

E-mail: acpeuker@hotmail.com

3 Programa de Pós-Graduação em Psicologia, Centro de Ciências da Saúde

E-mail: mariajulia.a@hotmail.com

4 Programa de Pós-Graduação em Psicologia, Centro de Ciências da Saúde

E-mail: mlalvesdesouza@outolook.com

5 Programa de Pós-Graduação em Psicologia, Centro de Ciências da Saúde

E-mail: elisakc@unisinos.br

* Dirección de correspondencia: Elisa Kern de Castro. Programa de Pós-Graduação em Psicologia, Centro de Ciências da Saúde. Avenida Unisinos 950, bairro Cristo Rei, CEP 92022-000, São Leopoldo, RS, Brazil. E-mail: elisake@unisinos.br 
Resultados y Conclusiones: Los resultados mostraron que no existían diferencias significativas en la percepción de riesgo y conductas de autocuidado entre mujeres con y sin historia familiar de cáncer de mama, lo que señala la necesidad de protocolos de trabajo para los psicólogos en la prevención del cáncer de mama en mujeres con historia familiar de enfermedad oncológica, lo que incluye la comprensión de los factores de riesgo y las causas de la enfermedad, así como su responsabilidad en el seguimiento.

Palabras clave: cáncer; cáncer de mama; autoregulación; autocuidado; prevención de enfermedades.

Sumario. 1. Introduction 2. Method 2.1. Participants 2.2. Instruments 2.3. Ethical Procedures 2.4. Data collection Procedures 2.5. Data Analysis 3. Results 4. Discussion 5. Conclusion 6. Funding 7. References.

Cómo citar: Ribeiro Seabra C, Peuker, AC, Armiliato MJ, Alves de Souza ML, Kern de Castro E. Early detection of breast cancer: the role of risk perception and family history. Psicooncologia 2017;14:83-92. DOI: 10.5209/PSIC.55813

\section{Introduction}

Breast cancer (BC) is the most common cancer among women, even in Brazil, accounting for approximately $25 \%$ of new cases of cancer each year ${ }^{(1)}$. The incidence of $\mathrm{BC}$ increases significantly from the age of 50 and, besides the age, early menarche (before eight years of age), late menopause (after the age of 50), the occurrence of the first pregnancy after 30 years of age, and/or not having had children are risk factors. Behavioral factors such as, for example, overweight and smoking, also increase the chances of the occurrence of BC. Family history (hereditary genetics) is an important risk factor for the illness. It is estimated that about $10 \%$ of cases of breast cancer are hereditary ${ }^{(2)}$.

The analysis of $\mathrm{BC}$ family history reveals the existence of specific characteristics that may indicate genetic risk, namely: families affected by $\mathrm{BC}$ for three consecutive generations, two or more relatives diagnosed in the premenopausal period, diagnosis of bilateral $\mathrm{BC}$ and even breast cancer in $\mathrm{men}^{(3,4)}$. The occurrence of mutations in BRCA1 and BRCA2 genes increases susceptibility to BC and is also related to ovarian cancer. The mutation in BRCA1 shows a risk of $57 \%$ of women developing breast cancer throughout their life, while the mutation in BRCA2 increases the risk by $49 \%$. Also, if the woman has mutation of these genes and has the diagnosis of $\mathrm{BC}$, it has increased risk of developing the illness in the other breast, especially if the woman is young $g^{(1,2,4-6)}$.

Genetic predisposition can only be confirmed by conducting genetic testing. This test is not carried out in Brazil by the Unified Health System, it is expensive and is, therefore, inaccessible to women (Brazil, 2013). Furthermore, there is controversy among experts about the usefulness of having the confirmation of gene mutation since the indication of invasive procedures such as mastectomy and ovary removal for preventive purposes is questionable ${ }^{(8)}$. However, for women at increased risk of breast cancer, there are some recommendations: 1) women should be familiar and aware ('breast cancer self-awareness') of their breast and report any changes to the doctor; 2) women should have the breasts examined by a clinician every 6-12 months from 25 years of age on and alternately perform breast ultrasound 
and mammography (annual MRI and alternating mammography) from 30 years every six months. To reduce the risk, bilateral prophylactic mammography and preventive chemotherapy have shown a reduced incidence of BC of up to $90 \%$ for women who have alterations in $\mathrm{BRCA} 1 / 2^{(2)}$.

In face of these issues, women with $\mathrm{BC}$ family history may show exacerbated concern regarding their health ${ }^{(9)}$, which can significantly interfere in their risk perception (RP) of developing the illness ${ }^{(10-12)}$. The risk perception concerns the individual understanding of the probability of being affected by an illness (vulnerability beliefs) ${ }^{(13,14)}$. In general, women with a family history tend to overestimate their risk for $\mathrm{BC}$ because of negative emotions related to the experiences with the family member who had the illness ${ }^{(12,15)}$.

Through their representations or perceptions, individuals model their health behavior both for illness prevention and for treatment compliance ${ }^{(16)}$. Therefore, it is understood that the perceptions of individual illnesses are modifiable. Through psychoeducation, for example, you can change the mindsets and erroneous beliefs about the illness ${ }^{(17)}$.

Women with a family history of the illness can be confronted with complex information on the risk of family members developing the illness, such as sisters and daughters ${ }^{(11,12)}$. Through routine consultations and also the media, women are exposed to plenty of information about the personal risk of developing $\mathrm{BC}$, especially those with a family history of the illness ${ }^{(2)}$. In some cases, these women can be consulted about this by their family members and also about ways of screening and prophylaxis. The challenge to process such information becomes even greater considering the vulnerability of women with a family history of breast cancer of developing the illness ${ }^{(9,18)}$. Although the experience of having had a very close family member with BC might have a negative effect on processing of information related to cancer, knowledge of being at risk could be an invitation for a woman to have a project for her health to be followed, in collaboration with the health system ${ }^{(9)}$. Women can, thus, be urged to take greater responsibility for their own health, which may have implications in self-care ${ }^{(19)}$.

Self-care is characterized by actions that people take deliberately to prevent illnesses and promote their health ${ }^{(19)}$. In the case of breast cancer, self-care is related to performing screening tests (mammography and breast ultrasound), gynecological consultations(clinical examination) and self-examination, in addition to maintaining a healthy lifestyle (not using drugs, regular practice of physical activities, etc.). Women with exacerbated RP, as a result of family history of breast cancer, when compared to women who have no family history, have higher repetition rates of screening tests ${ }^{(12)}$. Thus, this study was designed to compare the risk perception of breast cancer and self-care among healthy women with and without family history of the illness (first and second-degree kinship). It was hypothesized that women with a family history of breast cancer had a greater perception of risk of having the illness and, therefore, greater self-care.

\section{Method}

\subsection{Participants}

The study included 211 women over 40 years of age, users of primary care health service of a large city in the south of Brazil (mean age $=59.11$ years, $\mathrm{SD}=8.54$ ). 
Of these, 55 women (26.4\%) had a family history of breast cancer of first and/or second degree, and had not done tests to confirm genetic risk. The sample was selected consecutively among those who were waiting for checkup consultations at the women's and pediatrics clinic of a health center. Women with a personal history of breast cancer were excluded $(n=4)$.

\subsection{Instruments}

a) Sociodemographic, clinical and health behavior questionnaire: instrument developed by the authors to evaluate information regarding age, marital status, education, labor activity, medical history, and health behaviors (e.g. frequency of consultations and exams);

b) Risk perception questionnaire (adapted from Figueiras, 2014) ${ }^{(20)}$ : analogue questionnaire ranging in intensity from zero (no risk) to 10 (high risk). The questionnaireincludes four questions about breast cancer, namely: 1) To what extent do you think you can help reduce the risk of breast cancer?; 2) To what extent do you think you are at risk of having breast cancer?; 3) Compared to a person of your age and gender, to what extent do you believe that you are at risk of getting breast cancer?; 4) To what extent is breast cancer a serious illness?; For the evaluation of the answers, the mean of the scores of each item and the total mean are used.

\subsection{Ethical Procedures}

The research project was approved by the Research Ethics Committee of the Universidade do Vale do Rio dos Sinos - UNISINOS and the Health City Secretariat of Porto Alegre (Proceeding number 180/2014), in accordance with Resolution 466/2012 of the National Health Council, Brazil. Participants signed the informed consent form and the confidentiality of the information was assured.

\subsection{Data collection Procedures}

Women were invited to participate in the survey in the waiting rooms of the health center. They were informed about the objectives of the study and those who chose to participate in the study signed the Informed Consent Form - ICF. The instruments were applied by trained researchers, and answered individually in an appropriate place. After filling, the instruments were placed in envelopes with code numbers, separated from the ICF, without any personal identification. This procedure assures the secrecy and confidentiality of the information obtained.

\subsection{Data Analysis}

Data were tabulated and exported to the statistical program SPSS version 22.0. Initially, descriptive analyzes were performed (mean, standard deviation, frequency, percentages). Then inferential analyses of sociodemographic and health behavior variables were made. Mann-Whitney's test was performed to assess differences between the groups in the scores in the risk perception questionnaire. To examine 
associations between family history and self-care (questionnaire assessing health behaviors), the Chi-square test was conducted. The value of $\mathrm{p} \leq 0.05$ was used in the comparison analyses.

\section{Results}

Both the group of women with a family history of breast cancer $(n=55)$ and the group without the family history $(n=156)$ had a mean age of 59 years $(\mathrm{SD}$ $=8.23$ and 8.66 , respectively). In the group of women with a family history, among the family members who had had breast cancer, $43.6 \%(\mathrm{~F}=24)$ of them had died, 36.4\% $(\mathrm{F}=20)$ had survived without sequelae, 7.3\% $(\mathrm{F}=4)$ survived with sequelae (total mastectomy) and $20 \%(\mathrm{~F}=11)$ were still in treatment at the time of data collection. The family members were diagnosed on average 14.55 years before the interview $(\mathrm{SD}=12.94)$. The demographic data of the sample are described in table 1.

Table 1. Sociodemographic data.

\begin{tabular}{|c|c|c|c|c|c|}
\hline & & \multicolumn{2}{|c|}{$\begin{array}{l}\text { With family risk } \\
\qquad \begin{array}{l}\text { of } B C \\
N=55\end{array}\end{array}$} & \multicolumn{2}{|c|}{$\begin{array}{c}\text { Without family } \\
\text { risk of } \mathrm{BC} \\
\mathrm{N}=156\end{array}$} \\
\hline & & $\mathrm{F}$ & $\%$ & $\mathrm{~F}$ & $\%$ \\
\hline \multirow{4}{*}{ Marital Status } & Single & 13 & 23.6 & 28 & 17.9 \\
\hline & Married /Living with a partner & 19 & 34.5 & 72 & 46.2 \\
\hline & Separated & 14 & 25.5 & 36 & 23.1 \\
\hline & Widowed & 09 & 16.4 & 20 & 12.8 \\
\hline \multirow{3}{*}{ Education } & $\begin{array}{l}\text { Illiterate } \\
\text { Elementary School }\end{array}$ & $\begin{array}{c}2 \\
12\end{array}$ & $\begin{array}{c}3.6 \\
21.8\end{array}$ & $\begin{array}{c}2 \\
54\end{array}$ & $\begin{array}{c}1.3 \\
346\end{array}$ \\
\hline & High School & 25 & 45.5 & 81 & 51.9 \\
\hline & College & 16 & 29.1 & 19 & 12.2 \\
\hline Work & Yes & 20 & 36.4 & 58 & 37.2 \\
\hline Children & Yes & 45 & 81.8 & 140 & 90.3 \\
\hline
\end{tabular}

Regarding the indication of preventive examinations by gynecologists in their last routine consultation, $85.5 \%(\mathrm{~F}=47)$ of women with a history reported having received the indication for mammography, and $74.5 \%(\mathrm{~F}=41)$ reported receiving indication for breast ultrasound. In the group of women with no family history, $90.4 \%(\mathrm{~F}=141)$ said they had received indication for mammography and $63.5 \%(\mathrm{~F}$ $=99$ ) for ultrasound. 
Health self-care data in the group of women with and without a family history of the illness are described in Table 2. The chi-square test indicated that there were no significant associations between the health behaviors investigated (mammography, ultrasound, self-examination and routine gynecological consultations) and family history of breast cancer. Most women in both groups usually perform the indicated examinations and attend health services regularly.

Regarding the risk perception of developing breast cancer, the data showed that there are no significant differences between the groups in any of the questions of the questionnaire and on the overall score of risk perception (Table 03), showing that risk perception of women with and without family risk is similar. Moreover, there was no significant correlation between the time the family member had the illness and the risk perception of the participants.

Table 2. Health self-care data.

\begin{tabular}{|c|c|c|c|c|c|c|c|}
\hline & & \multicolumn{2}{|c|}{$\begin{array}{l}\text { With family } \\
\text { risk of BC } \\
\mathrm{N}=55\end{array}$} & \multicolumn{2}{|c|}{$\begin{array}{c}\text { Without } \\
\text { family risk of } \\
\text { BC N=156 }\end{array}$} & & \\
\hline & & M & SD & M & $\mathrm{SD}$ & & \\
\hline \multirow{2}{*}{\multicolumn{2}{|c|}{ Age of the first mammogram }} & $\begin{array}{l}37.02 \\
\text { years }\end{array}$ & 8.3 & $\begin{array}{l}40.94 \\
\text { years }\end{array}$ & 8.82 & & \\
\hline & & $\mathrm{F}$ & $\%$ & $\mathrm{~F}$ & $\%$ & $\mathrm{x}^{2}$ & $\mathrm{p}$ \\
\hline \multirow{3}{*}{$\begin{array}{l}\text { Frequency } \\
\text { of the } \\
\text { mammogram** }\end{array}$} & Does not perform & 6 & 10.6 & 8 & 5,1 & \multirow{3}{*}{2.526} & \multirow{3}{*}{0.28} \\
\hline & Within one year & 37 & 67.3 & 117 & 75.0 & & \\
\hline & Beyond one year & 9 & 16.4 & 30 & 19.2 & & \\
\hline \multirow{3}{*}{$\begin{array}{l}\text { Frequency } \\
\text { of the } \\
\text { ultrasound } * * *\end{array}$} & Does not perform & 16 & 23.6 & 54 & 34,6 & \multirow{3}{*}{1.097} & \multirow{3}{*}{0.58} \\
\hline & Within one year & 30 & 29.1 & 70 & 44.9 & & \\
\hline & Beyond one year & 9 & 54.5 & 26 & 16.7 & & \\
\hline \multirow{3}{*}{$\begin{array}{l}\text { Frequency } \\
\text { of the self- } \\
\text { examination }\end{array}$} & Does not perform & 12 & 21.8 & 51 & 32.7 & \multirow{3}{*}{2.331} & \multirow{3}{*}{0.312} \\
\hline & Seldom & 22 & 40 & 52 & 33.3 & & \\
\hline & Regularly & 21 & 38.2 & 53 & 34,0 & & \\
\hline \multirow{3}{*}{$\begin{array}{l}\text { Consultation } \\
\text { with a } \\
\text { gynecologist* }\end{array}$} & Does not perform & 0 & 0 & 7 & 4,5 & \multirow{3}{*}{3.401} & \multirow{3}{*}{0.183} \\
\hline & Within one year & 46 & 83.6 & 133 & 85.3 & & \\
\hline & Beyond one year & 8 & 14.5 & 15 & 9.6 & & \\
\hline
\end{tabular}

*one participant did not answer

** four participants did not answer

*** six participants did not answer. 
Table 3. Score in the Risk Perception Questionnaire.

\begin{tabular}{lcccccccc}
\hline & $\begin{array}{c}\text { With family } \\
\text { risk } \\
\text { of BC } \\
\mathrm{N}=55\end{array}$ & $\begin{array}{c}\text { Without } \\
\text { family risk } \\
\text { of BC } \\
\text { N=156 }\end{array}$ & & & & \\
& $\mathrm{M}$ & $\underline{\mathrm{SD}}$ & $\mathrm{M}$ & $\mathrm{SD}$ & $\mathrm{U}$ & $z$ & $\mathrm{p}$ \\
\hline & 8.01 & 2.23 & 7.93 & 2.44 & 4132.5 & -0.348 & 0.727 \\
\hline $\begin{array}{l}\text { Risk Perception } \\
\begin{array}{l}\text { RP 1 - Contribution to reduce the } \\
\text { risk of having BC }\end{array}\end{array}$ & & & & & & & \\
$\begin{array}{l}\text { RP 2 - Being at risk of having BC } \\
\text { RP 3 - Being at risk of having BC }\end{array}$ & 3.96 & 3.35 & 5.05 & 3.67 & 3572.5 & -1.744 & 0.81 \\
compared to another person & 4.78 & 3.08 & 5.18 & 3.12 & 3952 & -0.742 & 0.458 \\
$\begin{array}{l}\text { RP 4 - Severity of the BC } \\
\text { Total Risk Perception }\end{array}$ & 9.17 & 1.8 & 9.42 & 1.41 & 3898.5 & -1.251 & 0.211 \\
\hline
\end{tabular}

\section{Discussion}

The aim of this study was to compare BC risk perception and self-care of healthy women with and without family history of the illness ( $1^{\text {st }}$ and $2^{\text {nd }}$ degree kinship). The findings revealed that women with a family history had self-care behaviors similar to women with no history and did not perceive themselves at greater risk of having BC.

Regarding self-care, the fact that women in both groups perform preventive $\mathrm{BC}$ exams regularly and see the doctor regularly is very positive, indicating self-care with their health and autonomy ${ }^{(19)}$. It is observed that both women with and without history had similar self-care behaviors, which was a different result from another study ${ }^{(12)}$. However, the fact that the sample of this study was collected at the health center itself might have caused this result bias, since all the women attended the health care service. Perhaps if the sample had been collected at the women's own homes, the result would be different.

Women with a family history did not realize greater overall risk of having $\mathrm{BC}$ compared to women with no history. Despite possible personal risk and the experience of a close relative having had the illness ${ }^{(12)}$, this perception of higher risk might not have shown up clearly by lack of information from the participants, and by the fact that none of them has had genetic testing and counseling. Nevertheless, they do not consider their personal contribution in reducing the risk in the same way that women without a family history. This aspect deserves attention because it is from the perception of personal contribution to reducing the risk of the illness that preventive measures can be activated ${ }^{(21)}$. Therefore, it is important that the health psychologist can intervene in personal control beliefs to promote self-care and breast cancer prevention.

The literature indicates that patients with higher risk perception levels related to cancer may have more concerns and general distress ${ }^{(22,23)}$. In some cases, this distress cannot achieve clinical relevance. Nevertheless, chronic distress has been associated 
with increased health behaviors (e.g. screening) and biological responses that may be relevant to the risk of developing the illness in women with FH (e.g. impaired immune function, increased levels of cortisol, etc. $)^{(13)}$. Therefore, further studies can be developed to investigate variables that may be related to therisk perception of breast cancer, such as distress.

Women with $\mathrm{FH}$ of $\mathrm{BC}$ may believe they cannot do anything about the illness prevention because of heredity or the belief that the illness is hereditary and there is not much to be done ${ }^{(21)}$. In practical terms, the result of this study shows that in general women should be educated to realize their own contribution to the control of risk factors (e.g. healthy diet, regular physical exercise, etc.) The adoption of healthy lifestyle habits depends largely on how women perceive illness ${ }^{(19,21)}$. This may include beliefs about risk factors, personal vulnerability and the etiology of the illness. Further studies should explore the relationship between BC family history, risk perception, illness perception and their implications for self-care.

The present study had a number of limitations. Our sample was composed of public health service users and, therefore, people who have some care and concern for their health. Moreover, none of the women with a family history had had genetic testing, which can have an impact on the perception of individual woman's risk since there is no confirmation of this specific vulnerability.

New studies on the subject are important to clarify the phenomenon of preventive behaviors against breast cancer with family history. There is a clear need to raise awareness among women about the importance of breast cancer prevention and the consequences of lack of care based on their personal view of risk, and not on information about the illness and statistical data.

\section{Conclusion}

No significant differences in risk perception and self-care behavior among women with and without breast cancer history were found, signaling the need of guidelines for psychologists to act in breast cancer prevention among women with a family history, encompassing understanding of the risk factors and causes of the illness as well as women's responsibility in tracking. These results are relevant to guide the actions of the health psychologist in the prevention of breast cancer, given that healthy women with or without a history should be educated to realize their personal risk and their own contribution to the control of illness risk factors. Women with a family history of BC may believe that they have nothing to do about the prevention of the illness by virtue of heredity and, therefore, do not have adequate preventive behaviors of early detection (self-examination, doctor visits, imaging). Adopting healthy lifestyle habits (e.g. healthy diet, regular physical exercise, etc.) will depend largely on how the woman understands the risk factors and the etiology of the illness.

\section{Funding}

This research was funding National Council for Scientific and Technological Development of Brazil (CNPq). 


\section{References}

1. INCA. Instituto Nacional de Câncer José Alencar Gomes da Silva. 2016 [cited 2016 Aug 6]. Available from: http://www2.inca.gov.br/wps/wcm/connect/tiposdecancer/site/home/ mama/cancer_mama

2. Stuckey AR, Onstad MA. Hereditary breast cancer: an update on risk assessment and genetic testing in 2015. Am J Obstet Gynecol 2015; 213(2):161-5. DOI:10.1016/j. ajog.2015.03.003

3. Judkins T, Rosenthal E, Arnell C, Burbidge LA, Geary W, Barrus T, et al. Clinical significance of large rearrangements in BRCA1 and BRCA2. Cancer 2012; 118:5210-6. Doi: $10.1002 /$ cncr.27556

4. Powers J, Stopfer JE. Risk Assessment, genetic counseling, and clinical care for hereditary breast cancer. J Obstet Gynecol Neonatal Nurs 2014; 43:361-73. Doi: 10.1111/15526909.12304

5. Jackson SA, Davis AA, Li J, Yi N, McCormick SR, Grant C, et al. Characteristics of individuals with breast cancer rearrangements in BRCA1 and BRCA2. Cancer 2014; 120:1557-64. Doi: 10.1002/cncr.28577

6. Snape K, Ruark E, Tarpey P, Renwick A, Turnbull C, Seal S, et al. Predisposition gene identification in common cancers by exome sequencing: insights from familial breast cancer. Breast Cancer Res Treat 2012; 134:429-33. Doi: 10.1007/s10549-012-2057-x

7. Ministério da Saúde (BR). Nota técnica conjunta sobre o rastreamento do câncer de mama. 2013. [cited 2016 Aug 6]. Available from: http://www2.inca.gov.br/wps/wcm/ connect/a7973e0041bda572b9fefd4c0453ee90/Nota+conjunta+mamografia+2013.pdf? MOD=AJPERES\&CACHEID=a7973e0041bda572b9fefd4c0453ee90

8. Catania C, Feroce I, Barile M, Goldhirsch A, De Pas T, de Braud F, et al. Improved health perception after genetic counselling for women at high risk of breast and/or ovarian cancer: construction of new questionnaires--an Italian exploratory study. J Cancer Res Clin Oncol 2016; 142:633-48. Doi: 10.1007/s00432-015-2062-7

9. Caiata-Zufferey M. Genetically at-risk status and individual agency. A qualitative study on asymptomatic women living with genetic risk of breast/ovarian cancer. Soc Sci Med 2015;132:141-8. Doi: 10.1016/j.socscimed.2015.03.037

10. Fehniger J, Livaudais-Toman J, Karliner L, Kerlikowske K, Tice JA, Quinn J, et al. Perceived versus objective breast cancer risk in diverse women. J Womens Health 2014;23:420-7. Doi:10.1089/jwh.2013.4516

11. Gibbons A, Groarke A. Can risk and illness perceptions predict breast cancer worry in healthy women? J Health Psychol 2016;21:2052-62. Doi: 10.1177/1359105315570984

12. Haber G, Ahmed NU, Pekovic V. Family history of cancer and its association with breast cancer risk perception and repeat mammography. Am J Public Health 2012; 102:2322-9. Doi: 10.2105/AJPH.2012.300786

13. Molina Y, Ceballos RM, Dolan ED, Albano D, McGregor BA. Perceived breast cancer risk and breast cancer worry among women with a family history of breast cancer: a new perspective on coping as a mediator. Psychooncology 2015;24:113-6. Doi: 10.1002/ pon. 3587

14. Shiloh S, Wade CH, Roberts JS, Alford SH, Biesecker BB. Associations between risk perceptions and worry about common diseases: A between- and within-subjects examination. Psychol Health 2013; 28:434-49. Doi: 10.1080/08870446.2012.737464 
15. Heiniger L, Butow PN, Charles M, Price MA. Intuition versus cognition: a qualitative exploration of how women understand and manage their increased breast cancer risk. $\mathrm{J}$ Behav Med 2015;38:727-39. Doi: 10.1007/s10865-015-9632-7

16. Leventhal H, Bodnar-Deren S, Breland JY, Hash-Converse J, Phillips LA, Leventhal EA, et al. Modeling Health and Illness Behavior. In: Bawn, A., Revenson, T. A. \& Singer J, editors. Handbook of Health Psychology. New York: Routledge Handbooks; 2012. p. 3-35.

17. Leventhal H, Brissette I, Leventhal E. The Common-sense model of self-regulation of health and illness. In: Cameron LD, Leventhal H, editors. The Self-Regulation of Health and Illness Behaviour. London: Routledge; 2003. p. 42-65.

18. Hughes C, Lerman C, Schwartz M, Peshkin BN, Wenzel L, Narod S, et al. All in the family: evaluation of the process and content of sisters' communication about BRCA1 and BRCA2 genetic test results. Am J Med Genet 2002;107:143-50. Doi: 10.1002/ ajmg. 10110

19. Castro EK, Moro L. Factores psicosociales relacionados con el autocuidado en la prevención, tratamiento y postratamiento del cáncer de mama. Psicooncología 2013; 9:453-65. Doi:10.5209/rev_PSIC.2013.v9.n2-3.40916

20. Figueiras MJ. Escala de percepção de risco para cancro da mama. Instrumento não publicado. 2014.

21. Peuker ACWB, Armiliato MJ, de Souza L V., de Castro EK. Causal attribution among women with breast cancer. Psicol Reflexão e Crítica 2016;29:4. Doi: 10.1186/s41155016-0007-y

22. McCorry NK, Dempster M, Quinn J, Hogg A, Newell J, Moore M, et al. Illness perception clusters at diagnosis predict psychological distress among women with breast cancer at 6 months post diagnosis. Psychooncology 2013; 22:692-8. Doi: 10.1002/pon.3054

23. Van Esch L, Roukema JA, Ernst MF, Nieuwenhuijzen GAP, De Vries J. Combined anxiety and depressive symptoms before diagnosis of breast cancer. J Affect Disord 2012;136:895-901. Doi:10.1016/j.jad.2011.09.012 